\title{
Uji Coba Lagu Anak-anak Bertema Pendidikan
}

\author{
Wadiyo $^{1}$ dan Slamet Haryono \\ Fakultas Bahasa dan Seni, Universitas Negeri Semarang
}

\begin{abstract}
ABSTRAK
Media ajar berupa nyanyian atau lagu dipandang sangat penting untuk membantu pencapaian tujuan pendidikan yang dilakukan dalam suatu proses belajar mengajar baik formal maupun nonformal. Salah satu media ajar yang dapat digunakan untuk membantu anak-anak prasekolah dalam memahami pesan pendidikan adalah lagu anak-anak. Tujuan pokok penelitian ini adalah menguji penciptaan lagu anak-anak dikaitkan dengan daya gunanya untuk menyampaikan pesan pendidikan. Metode yang digunakan dalam penelitian ini adalah metode terapan. Subjek penelitian adalah para guru prasekolah. Langkah uji dilakukan dengan cara memperdengarkan lagu dan menirukan lagu yang diperdengarkan dan disampaikan pesan lagu dalam bentuk nyanyian. Hasil penelitian menunjukkan bahwa para guru tampak tertarik dengan lagu yang diperdengarkan. Selain itu, guru dapat dengan mudah menirukan lagu yang diperdengarkan dan menangkap isi atau pesan lagu.
\end{abstract}

Kata kunci: lagu anak-anak, lagu pendidikan

\begin{abstract}
Trying Out Children Songs with Educational Themes. Learning material in a form of songs is considered essential to support educational purposes of a certain teaching and learning process in formal, non-formal, and informal educations. Children song is one of several types of learning material which is used to help students in understanding educational messages. The main aim of this study is to deeply examine the creation of children song and to confirm whether the children song creation has been in line with its usability - which is to deliver educational messages to children. Method implemented in this research was developmental research, while the research subjects were preschool teachers. Stages in trying out the songs to the research subjects comprised three steps. First, subjects listened to the songs. Second, subjects imitated the songs and captured the meaning behind it. Third, subjects understood and analyzed the songs. The results show that the teachers, first, are interested on the songs. Second, teachers find no difficulties in imitating the songs. Lastly, teachers are able to easily understand the message delivered through the songs.
\end{abstract}

Keywords: children songs, song education

\section{Pendahuluan}

Tulisan ini menyampaikan proses uji coba dan hasil uji coba penciptaan lagu anak-anak yang dihasilkan oleh penulis untuk pendidikan anak-anak prasekolah. Saat ini, setiap lembaga pendidikan prasekolah sangat membutuhkan lagu anak-anak yang bertema pendidikan. Para guru prasejarah membutuhkan lagu bertema pendidikan sebagai materi bahan ajar. Tema pendidikan akan lebih mudah disampaikan pada peserta didik jika diberikan melalui lagu yang dinyanyikan. Dengan demikian siswa akan dapat menerima materi atau pesan pendidikan tersebut secara alami karena penyampaiannya melalui rasa. Otak yang berkait dengan logika secara lambat laun akan berkembang melalui sentuhan rasa. Supriyanti \& Suharto (2015) menjelaskan bahwa berkesenian memiliki

\footnotetext{
1 Alamat korespondensi: : Prodi Musik, FBS Universitas Negeri Semarang, Sekaran, Gunung Pati, Semarang
} 50229. E-mail: wadiyo@mail.unnes.ac.id 
kesamaan dengan dunia bermain yang berpengaruh terhadap tumbuh kembang anak yang baik dan berkarakter. Nilai-nilai positif dalam bermain dan berkesenian akan mempengaruhi aspek fisik, aspek perkembangan motor kasar dan halus, aspek sosial, aspek bahasa, aspek emosi, serta kepribadian anak.

Melalui berlagu atau bernyanyi, anak akan cenderung lebih mudah dalam menangkap pesan pendidikan. Berdasarkan pemikiran tersebut, uji coba atas hasil penciptaan lagu anak-anak ini penting dilakukan. Permasalahan pokok yang harus mendapat penyelesaian dalam penelitian ini adalah uji coba pengukuran daya guna produk lagu anakanak untuk prasekolah dalam kaitannya dengan tersampaikannya pesan pendidikan yang terdapat dalam lagu tersebut.

Lagu anak-anak yang digunakan oleh lembaga pendidikan prasekolah sebenarnya telah ada sekalipun dalam jumlah yang relatif sedikit. Lagu anak-anak yang jumlahnya relatif sedikit ini oleh masyarakat luas tidak jarang digunakan sebagai sarana berkesenian yang biasanya dilakukan dengan sambil melakukan berbagai aktivitas seperti ketika mengasuh anak, bermain dengan anak, atau bersenda gurau dengan anak. Anak bernyanyi lagu anak-anak justru ketika mereka bersama orang tua dan atau orang dewasa. Ketika mereka dalam kondisi sendiri, lagu yang dinyanyikan justru lagulagu untuk usia dewasa.

Fenomena ini muncul karena keberadaan teknologi yang mempengaruhi cara bersikap, berlaku, dan bertindak dengan menggunakan dan menirukan hal yang tersaji di media seperti hal-hal yang dilakukan oleh orang tua atau orang dewasa. Hal tersebut juga berpengaruh terhadap cara berkesenian. Saat ini, jarang sekali terdengar anak-anak yang menyanyikan lagu anak-anak. Materi lagu anak yang diberikan di sekolah merupakan materi lagu lama yang diajarkan secara turun temurun. Oleh karena itu, penciptaan lagu anak-anak untuk memasukkan tema-tema pendidikan melalui lagu-lagu tersebut penting untuk dilakukan. Hal ini sesuai dengan apa yang dikemukakan oleh Tyasrinestu (2014) dalam temuan penelitiannya yang menyebutkan bahwa fungsi lagu anak berbahasa Indonesia selain untuk belajar bahasa juga mengandung nilai pendidikan dan karakter positif untuk anak dengan kata-kata bermakna positif pada lirik-liriknya.

Di satu sisi, proses pendidikan untuk jenjang pendidikan prasekolah telah berjalan dengan baik. Dalam hal ini, kesadaran masyarakat untuk memasukkan putra putrinya ke bangku sekolah telah dimulai sejak usia dini. Jenjang pendidikan untuk usia dini disebut pendidikan prasekolah. Berbagai metode penyampaian pesan pendidikan dalam proses pembelajaran dilakukan oleh para guru pada jenjang pendidikan prasekolah ini tergantung pada tujuan pembelajaran yang ingin dicapai.

Bernyanyi merupakan salah satu metode penyampaian pesan pendidikan kepada anak didik. Melalui kegiatan bernyanyi, terdapat banyak hal yang bisa diperoleh anak seperti anak akan tumbuh rasa senang gembira, dapat berekspresi bebas dengan menggunakan suara dan gerak tubuhnya, serta dapat saling berinteraksi dengan kawankawan melalui lagu yang sama-sama dinyanyikan. Di sisi lain, melalui berlagu atau bernyanyi, anak akan dapat berkomunikasi dengan gurunya baik langsung maupun tidak langsung. Selain itu, siswa akan terasah emosi atau perasaannya melalui lagu yang dinyanyikan. Dalam hal ini, pesan nyanyian tentu dapat ditangkap dengan mudah dan dihayati tanpa melalui proses pemaksaan. Hal ini sesuai dengan apa yang telah dikemukakan oleh Rosmiati (2014) bahwa pada musik, selain dapat dijadikan media untuk membantu membentuk karakter anak, musik juga dapat digunakan sebagai sarana untuk mengatur tingkat emosional anak yang cenderung masih labil.

Lagu anak-anak yang diberikan dalam rangka menyampaikan pesan pendidikan jumlahnya masih sangat terbatas. Permasalahan utama sebenarnya bukan terletak pada minimnya jumlah lagu anakanak yang ada, namun pada masalah kemampuan penguasaan guru terhadap lagu-lagu tersebut. Hal ini terjadi karena beberapa hal terkait seperti kurangnya para guru mendapatkan pelajaran bernyanyi ketika masih duduk di bangku sekolah mulai prasekolah sampai jenjang yang lebih lanjut, kurangnya para guru mengakses lagulagu yang ada di berbagai media, kurangnya para guru mendapatkan kesempatan pelatihan untuk bernyanyi lagu anak-anak yang diselenggarakan 
oleh pihak Dinas Pendidikan atau instansi terkait lainnya, dan kurangnya kemampuan para guru untuk menciptakan lagu sendiri yang dapat memuat pesan pendidikan yang sesuai dengan tema pendidikan yang harus diajarkan.

Dalam hubungannya dengan sebuah proses pembelajaran umum dan pembelajaran musik bahwa kecakapan seorang guru kelas dalam mengatur kelas saat pelajaran berlangsung belum tentu dapat dipastikan menjadikan musik yang diajarkan mendapatkan kebermaknaannya. Hal yang perlu diperhatikan adalah potensi guru dalam memaknai musik dari aspek musikalitasnya, seperti mencari informasi yang terkait dengan wawasan musik dalam bingkai pendidikan anak-anak (Fitriani, 2014). Berdasarkan kondisi riil di sekolah khususnya jenjang pendidikan prasekolah saat ini, setidaknyalah untuk pendidikan prasekolah seperti di Taman Kanak-kanak, diwajibkan kepada peserta didik untuk menghapal dua puluh lagu anak dalam satu semester.

Kewajiban ini sungguh tidak mudah dilakukan oleh sekolah atau guru karena ketersediaan lagu yang bertema pendidikan yang cocok untuk anak prasekolah jumlahnya masih sangat terbatas. Selain itu, permasalahan lain muncul karena kemampuan para guru dalam menciptakan lagu bagi anak didik sesuai dengan tema yang diajarkan. Oleh karena itu, penelitian ini sangat penting dilakukan guna terciptanya lagu anak-anak bertema pendidikan untuk dapat dijadikan model penyampaian pesan pendidikan pada anak-anak. Berkait dengan hal tersebut dapat disampaikan tujuan dari penelitian ini, yakni menguji penciptaan lagu anak-anak dikaitkan dengan daya gunanya untuk menyampaikan pesan pendidikan.

Penelitian ini mengadopsi dari pemikiran Richey \& Klein (2005) sebagai suatu bentuk penelitian pengembangan. Oleh karena itu, hasil penelitian itu harus ditindaklanjuti dengan produk yang menjadi solusi atas kebutuhan tersebut. Produk yang sudah jadi sebagaimana yang telah dihasilkan pada penelitian di tahap pertama diujicobakan di lapangan untuk dilihat aspek daya gunanya.

Subjek penelitian ini adalah para guru yang akan mengajarkan lagu anak-anak di daerah Banjarnegara, Jawa Tengah. Sasaran kajian dalam penelitian ini berkaitan dengan aspek daya guna produk lagu anak-anak bertema pendidikan hasil karya cipta lagu produk penelitian yang telah dibuat oleh peneliti.

Penelitian ini mempergunakan sebelas tema pendidikan yang wajib digunakan dalam proses pembelajaran di tingkat pendidikan jenjang prasekolah. Sebelas tema itu terepresentasi dalam judul karya Diri Sendiri, Lingkunganku, Binatang, Tanaman, Rekreasi, Pekerjaan, Alat Komunikasi, Air, Udara, Api, Tanah Airku, dan Alam Semesta. Namun hanya lagu tertentu saja yang digunakan dalam uji coba untuk diterapkan pada para guru agar dapat dilihat respek para guru terhadap lagu tersebut.

\section{Hasil Penelitian dan Pembahasan}

Hasil penelitian ditampakkan berupa proses uji coba lagu anak-anak pada para guru sebagai personal yang akan menerapkan lagu anak-anak ini ke anak didik. Proses uji coba dan hasilnya diuraikan dalam tahapan sebagai berikut. Pertama, mendengarkan atau menyimak lagu yang diperdengarkan. Kedua, menirukan lagu yang telah diperdengarkan dengan memahami isi, pesan, atau makna lagu yang didengar atau ditirukan.

\section{Mendengarkan atau Menyimak Alur Lagu dan Pesan Lagu}

Peneliti mengujicobakan karya lagu anakanak agar lagu tersebut dikenal oleh para guru. Hal tersebut dilakukan dengan cara memperdengarkan lagu-lagu itu kepada para guru. Peneliti bertindak sebagai penguji coba, yang memperkenalkan lagulagu itu secara bergantian atau satu persatu kepada seluruh guru. Tindakan tersebut menggunakan metode analisis sintesis. Metode analisis sentesis adalah sebuah metode yang biasa digunakan oleh para guru dalam penyampaian materi ajar bidang apapun kepada para murid dengan cara memperkenalkan keutuhan materi terlebih dahulu. Selanjutnya, setelah sesuatu itu dikenal secara utuh, dijelaskan tentang elemen-elemen sesuatu yang telah disampaikan secara utuh tersebut (Ritchey, 1991). 
Nyanyian atau lagu yang diberikan untuk diperdengarkan kepada guru merupakan bentuk model lagu yang baru karena lagu itu benarbenar baru sebagai hasil dari ciptaan peneliti yang memang dibuat untuk menyampaikan pesan pendidikan untuk anak didik, khususnya anakanak prasekolah karena lagu itu merupakan bentuk ciptaan yang baru. Lagu itu harus diperkenalkan atau diperdengarkan secara utuh terlebih dahulu agar dikenali oleh pendengar atau partisipator penelitian secara utuh pula. Keutuhan lagu ini diharapkan akan merangsang pendengar secara utuh pula agar si pendengar tidak memahami lagu secara sepotong-potong. Selain itu, nuansa estetik dari lagu juga dapat dirasakan penuh oleh pendengar atau apresiator, yang dalam konteks ini adalah para partisipan dalam penelitian ini.

Berkait dengan pesan ini, menurut Raj \& Muniapan (2012), pesan dapat berupa nilai, kepercayaan, pengetahuan, norma atau makna tertentu dalam motif, bentuk, gaya pada hasil karya tadi. Keberhasilan penyampaian pesan-pesan bergantung pada kemampuan masyarakat dalam menangkapnya dengan mengacu pada nilai-nilai budaya dan norma-norma sosial yang hidup. Oleh karena itu, selama seniman menjadikan nilai-nilai budaya dan norma-norma sosial sebagai acuan dalam mengungkapkan pesan-pesan secara indah, selama itu pula ia akan berhasil membina hubungan dengan masyarakat pendukungnya.

Kesenian berwujud dari adanya dorongan rasa keindahan manusia. Dorongan rasa keindahan itu tidak terbebas dari perasaan dan pikiran yang terbentuk pada diri manusia/seniman melalui proses sosialisasi aktif dengan lingkungannya. Sehubungan dengan hal itu, kesenian boleh dikatakan sebagai ungkapan sosial yang merupakan bagian dari kebudayaan yang erat sekali kaitannya dengan unsur-unsur kebudayaan yang lain. Oleh karena itu, Keesing (1990) menyimpulkan bahwa kesenian dengan berbagai wujudnya mempunyai banyak fungsi sosial yang memiliki nilai penting sebagai pembinaan masyarakat dan kebudayaan yang bersangkutan.

Suatu lagu sebagai sebuah karya seni selalu mengandung pesan-pesan. Pesan dimengerti sebagai suatu isi, baik yang tersurat maupun yang tersirat di dalam seni tersebut. Berhubung seni bersifat halus maka pesan yang disampaikan melalui karya seni cenderung dapat diterima dengan perasaan damai. Namun demikian, dengan sifatnya yang halus itu, tidak setiap orang dapat menangkap pesan seni tersebut. Menurut Chernets (2010) dan Kemp (2003), penangkapan makna tersebut bergantung kepekaan daya tangkap masing-masing individu.

Rahim (2009) menerangkan bahwa pesan seni yang disampaikan melalui kehalusan/ keindahan tidak menjadikan orang menjadi sakit hati, dan justru mereka berkesenian dengan berbagai hal yang dapat dijadikan alat ungkap bagi dirinya atau dijadikan sebagai sarana berekspresi bagi dirinya. Lagu yang menyampaikan pesan pendidikan akan berkaitan dengan sebuah cara pembelajaran yang diterapkan dalam sebuah proses belajar mengajar.

Cara penyampaian pesan pendidikan dipahami sebagai suatu prosedur yang ditempuh untuk mencapai pembelajaran yang optimal. Namun cara dalam suatu pembelajaran bukanlah suatu tujuan melainkan suatu strategi yang sistematik yang digunakan untuk mencapai tujuan pembelajaran yang sebaik-baiknya. Suatu cara juga dapat dikatakan sebagai suatu usaha yang dilakukan oleh pendidik untuk dapat menciptakan situasi belajar mengajar yang menguntungkan (Ehrlin \& Gustavsson, 2015; Jacobsen, Eggen, \& Kauchak, 2009).

Keutuhan lagu yang diperdengarkan dalam kaitannya untuk menyampaikan pesan mengandung beberapa unsur musik yang lain seperti irama, melodi, dan harmoni. Irama adalah urutan rangkaian gerak yang menjadi unsur dasar musik. Irama juga bisa dipahami sebagai sebuah hitungan metrik sederhana maupun berganda yang menjadi pola dasar dari gerakan melodi. Melodi adalah susunan rangkaian nada yang terdengar berurutan serta berirama dengan nilai nada yang variatif. Melodi juga bisa dikatakan sebagai sebuah rangkaian nada yang berbeda satu sama lain dari tinggi, rendah, dan panjang suara yang membentuk motif dan kalimat musik. Harmoni adalah keselarasan nada. Dapat pula dijabarkan bahwa harmoni adalah keselarasan bunyi baik vertikal maupun horisontal dari sebuah rangkaian bunyi atau nada dan atau melodi (Wright, 2011). 
Berikut adalah contoh lagu anak-anak yang diujicobakan untuk para guru agar dapat dilihat seberapa jauh pengaruh lagu tersebut dapat digunakan sebagai lagu yang bisa diberikan untuk anak didik sebagai alat atau media penyampaian pesan pendidikan.

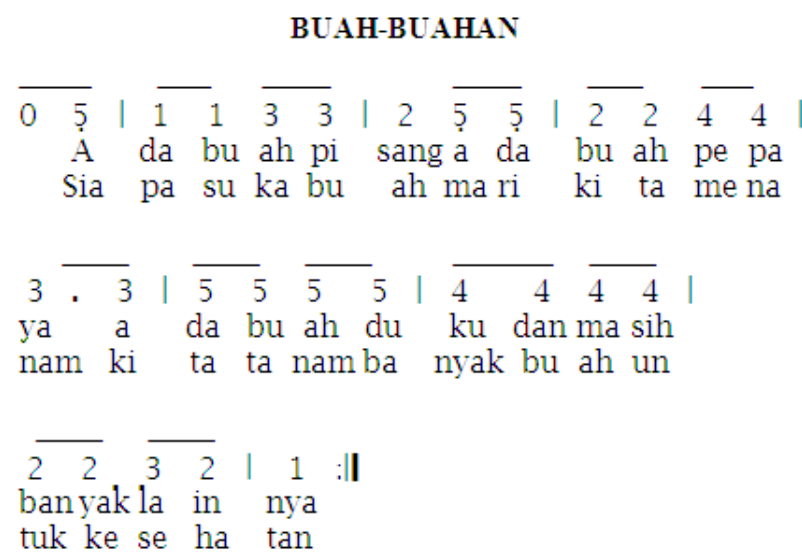

\section{KUPU-KUPU}

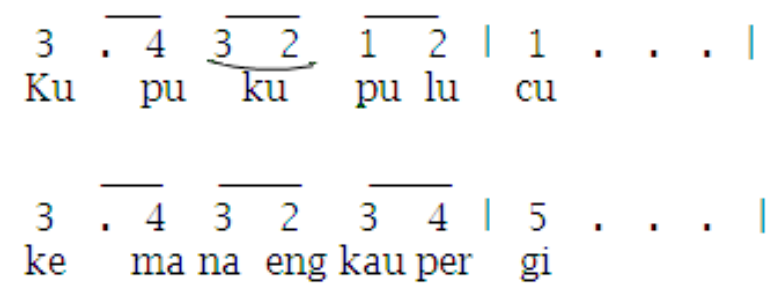

$2 \overline{2} 25 \overline{34} \mid \begin{array}{llll}32 & 1\end{array}$ kau ter bang ke sa na ke ma ri
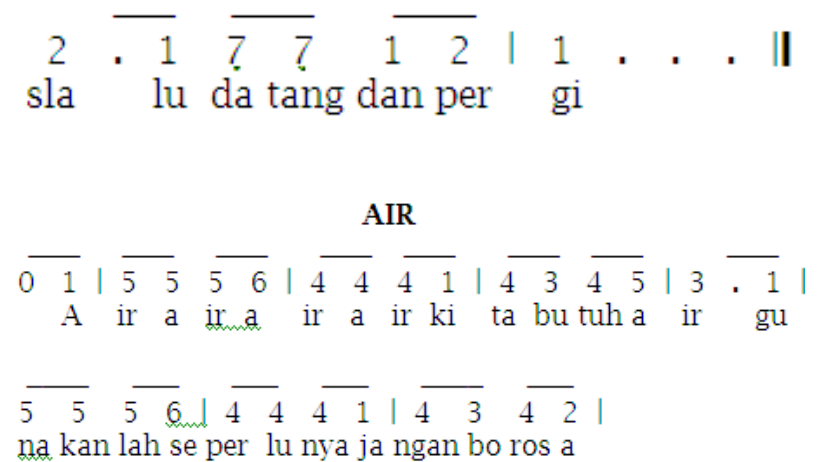

$1 \overline{0}|\overline{22} \overline{22}| 40 \overline{5}$ |

ir man di pakaia ir nyu

$\overline{3} 3 \overline{3} 3|3 \overline{0}| \overline{22} \overline{22}$ |

ci pa kaia ir mi num jug a a

$4 \overline{45}|\overline{32} \overline{12}| 1$ ||

ir semu a but uh a ir

\section{BANYAK KAWAN DAN TEMAN}

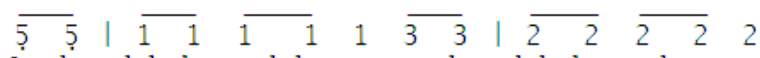
se ko lah ba nyak ka wanse ko lah ba nyak te man

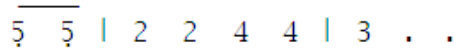

ki ta da pat ber ma in

$\overline{13}|\overline{55} \overline{55} 4 \overline{54}| \overline{33} \overline{33} 3$ ber ma in de ngan ka wan ber ma in de ngan te man

$\overline{43}\left|\begin{array}{llllllll}2 & 2 & 2 & 3 & 2 & \mid & 1 & 0\end{array}\right|$

berma in ha ti ku se nang

\section{JAMBU}

$\overline{05}|\overline{32} \overline{1} 2| 3 \overline{4}|\overline{3} 2 \overline{1} 2| 3$ Jam bu jambu jam bu si a pa su ka jam bu

$\overline{02}|\overline{22} \overline{34}| 5 \overline{52}|\overline{22} 3 \overline{3}| 5$ jam bu a da yang pu tih dan a da yang me rah

$\overline{02}|\overline{22} \overline{34}| 5 \overline{52}|\overline{22} \quad \overline{3}| 5$ jam bu a da yang ma tang dan a da yang men tah

$0|\overline{66} \overline{6 i}| 55|\overline{66} \overline{6 i}| 5$ sia pa su ka jam bu jam bu yang men tah

0 | $25 \overline{34} \mid \begin{array}{lllll}252 & 52 & 1\end{array}$ sia pa su ka jam bu jam bu yang ma tang

\section{Menirukan Nyanyian dan Penangkapan Pesan}

Tahapan setelah subjek penelitian memperhatikan dengan cara menyimak lagu yang diperdengarkan untuk dapat ditangkap tentang alur lagu dan pesan lagunya, subjek penelitian akan menirukan lagu yang diperdengarkan dengan cara menyanyikannya. Untuk dapat bernyanyi dengan cara menirukan lagu yang telah diperdengarkan, alur motif, alur frase, dan kalimat lagu harus ditangkap subjek secara utuh. Dalam hal ini, motif adalah potongan lagu terkecil yang telah mempunyai makna. Sementara itu, frase adalah gabungan dari dua motif dan atau berupa kalimat pertanyaan atau kalimat pernyataan, sedangkan adanya kalimat pertanyaan atau kalimat pernyataan dengan kalimat jawaban mewujudkan bagian lagu atau bentuk lagu (Wright, 2011).

Para guru dalam menyanyikan lagu tersebut menggunakan cara dengan mengikuti alur 
nyanyian. Alur tersbut dimulai dari menyanyikan satu motif yang dirangkai dengan motif berikutnya sehingga mewujudkan frase (kalimat pertanyaan atau kalimat pernyataan) serta kalimat jawaban yang berhenti pada bentuk utuh sebagai bagian akhir dan di ulang-ulang sampai mereka hafal lagu tersebut. Beberapa lagu digunakan dengan cara yang sama. Cara ini menjadi tampak efektif dan kreatif karena mereka juga sambil meperagakan gerakan menyesuaikan irama lagu yang disesuaikan dengan pesan nyanyian. Cara bernyanyi dengan pola gerakan menjadi kebiasaan para subjek penelitian yang memang profesinya sebagai guru anak prasekolah. Guru prasekolah harus dapat menyampaikan pesan lagu kepada anak-anak dengan berbagai cara.

Jika dilihat dari proses penciptaannya, cara bernyanyi seperti yang dilakukan oleh guru-guru prasekolah tampaknya memiliki benang merah atau keterhubungan yang dekat. Proses suatu penciptaan lagu dapat dimulai dengan berbagai cara. Pertama, dengan menciptakan melodi terlebih dahulu, lalu diberi syair yang memuat pesan lagu. Kedua, membuat syair sebagai sebuah pesan lagu terlebih dahulu, baru kemudian diciptakan melodinya. Ketiga, adalah antara melodi dan syair yang berisi atau bermuatkan pesan lagu dibuat secara bersama (Raj \& Muniapan, 2012). Lagu merupakan bagian dari musik sedangkan musik merupakan suatu karya seni. Penciptaan lagu sebagai suatu karya seni menurut teori kreativitas individu versus bentuk budaya mapan selalu tergantung oleh bentukbentuk budaya yang sudah ada dan telah mapan di masyarakat (Ryan \& Brown, 2012). Hal yang dilakukan oleh para guru sebagai subjek penelitian tampaknya bertujuan untuk mengekspresikan segala sesuatu dalam hubungannya dengan hal yang dilakukan sehari-hari dalam menjalankan profesinya untuk menyampaikan pesan pendidikan pada anak didik berpijak pada budaya yang digunakan sebagai acuan dengan bersikap dan bertindak.

Dalam hubungan dengan itu, bentuk musik atau lagu dianggap telah mapan apabila dalam sebuah perwujudan karya cipta musik atau lagu, baik motif-motif, frase-frase, maupun kalimatkalimat musik, telah dirangkai menjadi satu. Clive Bell, seorang filsuf dari Jerman, mengungkapkan bahwa seni penglihatan dan musik sepanjang masa memiliki bentuk penting sehingga seni itu dihargai masyarakat. Istilah yang dipergunakan Bell ialah significant form. Pendapat dari Clive Bell ini diulas secara detil oleh Zeki (2013).

Sesungguhnya segala bentuk karya seni yang dihasilkan oleh suatu masyarakat tidak terbebas dari pengaruh kebudayaan yang berlaku. Besarnya daya imajinasi dan kreativitas seorang seniman dalam melakukan proses penciptaan, ia senantiasa merujuk pada nilai-nilai budaya, norma-norma sosial atau pandangan hidup yang berlaku di masyarakat. Keluarga sebagai bagian dari masyarakt juga memiliki peran dalam membentuk karakter seorang anak. Disampaikan oleh Youm (2013) bahwa pendidikan musik yang diajarkan oleh orangtua pada usia dini nyatanya berpengaruh pada pola anak dalam berperilaku dan bersosialisasi. Seniman dikatakan berhasil bukan hanya karena karya-karyanya memenuhi ukuran keindahan yang relatif, melainkan karena kemampuannya dalam menyampaikan pesan-pesan budaya secara indah. Hal tersebut sesuai yang dilakukan oleh para guru sebagai subjek penelitian yaitu menangkap pesan lagu dan mengekspresikan kembali untuk menyampaikan isi dari lagu atau nyanyian tersebut.

Hal yang dilakukan oleh para guru dalam konteks uji coba produk lagu anak-anak dalam penelitian ini dapat bisa dibandingkan dengan hasil penelitian yang dilakukan oleh Wadiyo (2015). Pesan pendidikan yang ada di dalam lagu cukup diberikan oleh guru kepada anak didik dengan cara anak didik diajak bernyanyi bersama dengan ekspresi sebebas-bebasnya sesuai alam dan budaya anak. Sebelum atau setelah bernyanyi, guru secara verbal menyampaikan pesan lagu tersebut kepada anak didik untuk menegaskan pesan lagu tersebut. Namun demikian keterangan verbal tersebut tidak mudah melekat terutama pada anak didik yang masih usia prasekolah. Berbeda halnya dengan ketika ia menghayati nyanyiannya.

Dalam hubungannya dengan hasil penelitian Wadiyo itu sebelumnya juga telah dipaparkan oleh Caine \& Caine (1991) dalam buku berjudul Teaching and the Human Brain dan juga didukung oleh hasil penelitian dari Supradewi (2010) bahwa pencitraan musik atau lagu dapat memicu imajinasi 
anak dan akan membuat pesan musik atau lagu dapat ditangkap oleh anak dengan mudah. Dalam pengertian yang lebih luas dikemukakan bahwa melalui pencitraan lagu akan dapat membantu anak untuk memecahkan problem kesulitan belajar atau kesulitan menerima materi pelajaran yang dianggap paling sulit sekalipun. Untuk ini dapat dipahami bahwa hal yang dilakukan oleh para guru dalam menyanyikan lagu juga seolaholah mereka mengajarkan lagu pada anak untuk menyampaikan pesan pendidikan yang termuat dalam lagu sekaligus berekspresi estetik lewat lagu atau nyanyian itu.

\section{Penutup}

Berdasar hasil penelitian dapat disimpulkan bahwa produk lagu anak-anak yang diujicobakan pada para guru yang menjadikan produk ini sebagai media bahan ajar untuk menyampaikan pesan pendidikan pada anak-anak prasekolah yang dilakukan dengan cara bernyanyi. Guru dengan mudah menyanyikan lagu tersebut sebagai media bahan ajar untuk para anak didik prasekolah. Guru dapat menangkap pesan lagunya seolah ia telah mengajarkannya pada anak didik.

\section{Kepustakaan}

Caine, R. N., \& Caine, G. (1991). Teaching and The Human Brain. Alexandria: Association for Supervision and Curriculum Development.

Chernets, V. (2010). Art and Aesthetics: Nature and the Specific Relationship and Interaction. Interdisciplinary Approach to Economics and Sociology, 3(2), 114-120.

Ehrlin, A., \& Gustavsson, H.-O. (2015). The Importance of Music in Preschool Education. Australian Journal of Teacher Education, 40(7), 32-42.

Fitriani, Y. (2014). Model Pembelajaran Seni Musik melalui Lesson Study: Studi Kasus di SD Jawilan Serang. Resital, 15(2), 126-138. Jacobsen, D. A., Eggen, P., \& Kauchak, D. (2009). Methods for Teaching (8th ed.). Boston: Pearson Education.

Keesing, R. M. (1990). Theories of culture revisited.
Canberra Anthropology, 13(2), 46-60.

Kementrian Pendidikan dan Kebudayaan. (2015). Menteri Pendidikan dan Kebudayaan Republik Indonesia Nomor 146 Tahun 2015 tentang Kurikulum 2013 Pendidikan Anak Usia Dini.

Kemp, R. (2003). Aesthetics Perspectivalism and the Nature of Art: Two Proposals Attemting to Develop a Theology of the Arts. IIIM Magazine Online, 5(22), 1-11.

Rahim, M. A. (2009). Seni dalam Antropologi Seni. Imaji, 5(2), 44-55.

Raj, S. J., \& Muniapan, B. (2012). Music, Song Lyrics, Philosophy, and Human Values: Exploring Poet Kannadasan's Contributions. International Refereed Research Journal, 3(4 (2)), 1-12.

Richey, R. C., \& Klein, J. D. (2005). Developmental Research Methods: Creating Knowledge from Instructional Design and Development Practice. Journal of Computing in Higher Education, 16(2), 23-38.

Ritchey, T. (1991). Analysis and Synthesis On Scientific Method - Based on a Study by Bernhard Riemann. System Research, 8(4), 21-41.

Rosmiati, A. (2014). Teknik Stimulasi dalam Pendidikan Karakter Anak Usia Dini melalui Lirik Lagu Dolanan. Resital Jurnal Seni Pertunjukan, 15(1), 71-82.

Ryan, T. G., \& Brown, K. (2012). Musical Creativity : Measures and Learning. Journal of Elementary Education, 22(2), 105-120.

Supradewi, R. (2010). Otak, Musik, dan Proses Belajar. Buletin Psikologi, 18(2), 58-68.

Supriyanti, S., \& Suharto, D. (2015). Penciptaan Tari Manggala Kridha sebagai Media Pembentukan Karakter bagi Anak. Journal of Urban Society's Arts, 2(1), 18-24.

Tyasrinestu, F. (2014). Lirik Musikal pada Lagu Anak Berbahasa Indonesia. Resital, 15(2), 163-168.

Wadiyo, W. (2015). Music as an Integrated Education Tool for Preschool Students. Harmonia: Journal of Arts Research and Education, 15(2), 144-151. https://doi. org/10.15294/harmonia.v15i2.4691 
Wright, C. (2011). Listening to Music (6th ed.). Boston: Schirmer.

Youm, H. K. (2013). Parents Goals, Knowledge, Practices, and Needs Regarding Music Education for Their Young Children in South Korea. MENC: The National Association for
Music Education, 61 (3), 280-302. https:// doi.org/10.1177/0022429413497233

Zeki, S. (2013). Clive Bell's "Significant Form" and the neurobiology of aesthetics. Frontiers in Human Neuroscience, 7 (November), 1-14. https://doi.org/10.3389/fnhum.2013.00730 